\title{
EVALUASI PROSES PROGRAM REHABILITASI LOW VISION YAYASAN LAYAK JAKARTA DALAM UPAYA PENCEGAHAN KEBUTAAN PADA ANAK
}

\author{
Habib Rachman Aji dan Ahmad Zaky \\ UIN Syarif Hidayatullah Jakarta \\ Email: habibrachman8@gmail.com
}

\begin{abstract}
Visual impairment is a problem experienced by many children in developing countries. Uncorrected refraction disorders, cataracts, glaucoma, and visual disturbances that have been experienced since childhood are some of the things that cause a person experiencing visual disturbances. This study aims to find out the description and explanation of the implementation of low vision rehabilitation carried out by the Low Vision Layak Foundation Jakarta. This study uses a qualitative approach to the type of descriptive research. While data collection techniques are carried out through observation, interviews and documentation. For the selection of informants in this study using purposive sampling technique, the sample is taken intentionally. The results of this study indicate that the attitude shown by the officer has made the client feel confident and the services provided are right on target. In terms of facilities and infrastructure have met the standards of the institution but there is one room that is considered too small and requires another room for counseling. It would be nice to have a review conducted by the Layak Foundation related to these obstacles. And until now there are some children who are rarely evaluated. In the future, client evaluations should be carried out routinely.
\end{abstract}

Keywords: Process Evaluation, Low Vision, Blindness, Children.

Abstrak. Gangguan penglihatan merupakan permasalahan yang banyak dialami oleh anak-anak di negara berkembang. Kelainan refraksi tidak terkoreksi, katarak, glaucoma, dan gangguan penglihatan yang dialami sejak masa kanak-kanak merupakan beberapa hal yang menyebabkan seseorang mengalami gangguan penglihatan. Penelitian ini bertujuan untuk mengetahui gambaran dan penjelasan mengenai pelaksanaan rehabilitasi low vision yang dijalankan oleh Low Vision Yayasan Layak Jakarta. Penelitian ini menggunakan pendekatan kualitatif dengan jenis penelitian deskriptif. Sementara teknik pengumpulan data dilakukan melalui observasi, wawancara dan dokumentasi. Untuk pemilihan informan pada penelitian ini menggunakan tekhnik purposive sampling, yaitu sampel yang dimbil dengan sengaja. Hasil penelitian ini menunjukan bahwa sikap yang ditunjukkan oleh petugas telah membuat klien merasa yakin dan layanan yang diberikan sudah tepat pada sasaran. Dari segi sarana dan prasarana telah memenuhi standar lembaga akan tetapi ada ada satu ruangan yang dianggap terlalu kecil serta membutuhkan satu ruangan lain untuk konseling. Alangkah baiknya ada peninjauan kembali yang dilakukan oleh pihak Yayasan Layak terkait kendala tersebut. Dan sampai saat ini ada beberapa anak yang jarang di evaluasi. Untuk kedepannya mungkin evaluasi klien harus rutin untuk dilakukan.

Kata Kunci: Evaluasi Proses, Low Vision, Kebutaan, Anak 
Evaluasi Proses Program Rehabilitasi Low Vision Yayasan Layak Jakarta dalam Upaya Pencegahan Kebutaan pada Anak

- Habib Rachman Aji dan Ahmad Zaky

\section{Pendahuluan}

Gangguan penglihatan (Visual Impairment) merupakan suatu permasalahan yang banyak dialami oleh anak-anak di beberapa negara berkembang, Indonesia merupakan salah satunya. UNICEF (United Nations Children's Fund) mencatat sebanyak 1,4 juta anak mengalami gangguan penglihatan dengan perincian 1 juta di kawasan Asia, dan 400 ribu di kawasan Afrika (Depkes, 2018). Kelainan refraksi yang tidak terkoreksi menjadi penyebab utama gangguan penglihatan, diikuti dengan katarak, glaucoma, dan gangguan penglihatan yang di alami sejak masa kanak-kanak. Kementrian Kesehatan Rebuplik Indonesia menegaskan harus ada upaya penanggulanan gangguan penglihatan maupun kebutaan sejak dini karena angka gangguan penglihatan kini telah meningkat tajam.

Menurut World Health Organization (WHO) urutan kondisi penglihatan manusia terbagi menjadi empat bagian yaitu penglihatan normal, gangguan penglihatan sedang, gangguan penglihatan berat, dan yang terakhir buta (Asrorudin 2014). Apabila orang-orang dengan gangguan penglihatan sedang tidak mendapat pelayanan yang maksimal maka itu akan mengakibatkan gangguan penglihatan yang semakin parah dan tidak menutup kemungkinan akan mengalami kebutaan. Untuk itu perlu adanya pencegahan gangguan penglihatan tertutama pada anak. Selanjutnya WHO memberi pernyataan bahwa 500 anak buta tiap tahun atau 1 di antara 1.000 anak mengalami kebutaan per menit. Sementara angka kebutaan di Indonesia mencapai 3\% dan sebanyak 81\% karena katarak (Depkes, 2018).

Dijelaskan dalam Jurnal e-Clinic (eCI) gangguan penglihatan merupakan masalah yang tidak dapat dianggap remeh, terutama pada anak. Karena $80 \%$ informasi selama 12 tahun pertama pada kehidupan anak didapat melalui penglihatan (Dalope 2017). Setidaknya setiap 6 bulan sekali orang tua harus membawa anaknya untuk melakukan pemeriksaan mata. Pemeriksaan mata secara berkala merupakan cara yang tepat yang dapat dilakukan oleh orang tua untuk mencegah anak mengalami gangguan penglihatan.

Untuk membantu dan mendukung anak yang mengalami gangguan penglihatan dalam melakukan kegiatannya, tentu bukan hanya orang tua saja yang berperan, guru sebagai orang tua di sekolah pun juga memiliki peran yang tidak kalah penting. Orang tua dituntut untuk selalu mengetahui semua kegiatan yang dilakukan oleh sang anak. Karena di beberapa kasus gangguan penglihatan 
yang bertambah parah disebabkan oleh aktivitas anak di luar rumah, di mana tidak ada orang tua yang mengawasi mereka. Sudah selayaknya para orang tua mengawasi, menjaga serta merawat anak-anak mereka.

Dalam beberapa kasus ditemukan kekeliruan orang tua dalam merawat dan menjaga aktivitas anak dengan gangguan penglihatan. Seperti halnya contoh kasus seorang anak berusia 9 tahun bernama Imam yang penglihatannya semakin memburuk karena sering lupa diri jika bermain bola dengan teman-temannya. Sang ibu mengatakan bahwa dirinya kurang telaten dalam mengikuti keseharian anaknya di sekolah, beliau juga tidak mengetahui bahwa sang anak sering menyundul bola. Ahli refraksi yang memeriksa Imam mengatakan kebiasaan menyundul bola sangat berpengaruh terhadap penglihatannya kini semakin memburuk (Detikcom, 2015). Itulah mengapa orang-orang yang berada di sekitar sang anak sangat dibutuhkan perannya untuk menjaga dan mencegah gangguan penglihatan yang semakin memburuk. Dan yang harus diingat adalah merawat dan menjaga anak yang mengalami gangguan penglihatan membutuhkan kesabaran dan ketelatenan.

Dengan angka kebutaan yang sudah mencapai 3\%, permasalahan gangguan penglihatan ini tidak lagi dianggap menjadi permasalahan kesehatan saja melainkan sudah menjadi permasalahan sosial. Untuk itu pemerintah dan dibantu oleh lembaga yang menangani permasalahan ini perlu mengambil tindakan untuk menuntaskan atau sekedar mengurangi peningkatan angka kebutaan di Indonesia. Terkait permasalahan ini ada suatu yayasan yang telah bekerja dalam hal mengurangi dan mencegah peningkatan angka kebutaan di Indonesia khususnya anak-anak. Yayasan Pelayanan Anak dan Keluarga, atau yang biasa disebut Yayasan Layak adalah sebuah yayasan yang sampai saat ini bergerak dalam bidang pelayanan untuk anak dan keluarga. Sejak tahun 2015, Layak bekerjasama dengan Christian Blind Mission (CBM) dan Standart Chartered Bank (CBM) mengembangkan program low vision dan juga pencegahan kebutaan di Indonesia melaui program Seeing Is Believing (SIB) dengan melakukan rehabilitasi low vision yang dilakukan untuk daerah Jabodetabek dan Sulawesi Selatan (Layak, 2018).

Low Vision Yayasan Layak menjadikan anak berusia 0-18 tahun sebagai fokus populasi target layanan (meskipun tidak menutup kemungkinan terdapat orang dewasa yang perlu mendapatkan pelayanan) karena mereka menganggap bahwa anak-anak masih memiliki masa depan yang panjang oleh karena itu 


\section{Evaluasi Proses Program Rehabilitasi Low Vision Yayasan Layak Jakarta dalam Upaya Pencegahan Kebutaan pada Anak}

- Habib Rachman Aji dan Ahmad Zaky

perlu dipersiapkan perkembangannya sedini mungkin. Low Vision Yayasan Layak berupaya untuk mengembangkan model layanan low vision yang komprehensif dan terintegrasi antara pelayanan kesehatan, pendidikan dan masyarakat, peningkatan kapasistas Sumber Daya Manusia (SDM) tentang penanganan low vision disemua level layanan seperti dokter mata, refraksionis, perawat kesehatan mata, guru Sekolah Luar Biasa, guru sekolah umum dan inklusi, masyarakat dan lain sebagainya (Layak 2018).

Sampai dengan bulan Agustus 2018, jumlah anak dengan gangguan penglihatan, low vision, dan disabilitas yang lain yang telah menerima layanan dari Low Vision Yayasan Layak berjumlah 1.302 anak. Jumlah itu terbagi di dua kota, yaitu DKI Jakarta berjumlah 752 anak dan di Makassar berjumlah 550 anak. Dari jumlah penerima layanan tersebut sebagian besar rujukan berasal dari bidang Pendidikan (Sekolah Luar Biasa \& Inklusi ), layanan kesehatan ( rumah sakit, klinik mata, praktek dokter, optik) dan kader masyarakat ( RBM, dan Panti Sosial) (Layak, 2018). Untuk kedepannya tentu akan ada peningkatan jumlah klien yang akan dilayani. Oleh karena itu penulis berkeinginan untuk melakukan evaluasi karena penulis menilai bahwa program rehabilitasi Low Vision Yayasan Layak telah banyak membantu orang dengan gangguan penglihatan khususnya anak-anak. Dari hasil evaluasi ini nantinya pihak Low Vision Yayasan Layak akan meningkatkan kualitas pelayanan mereka dan memperbaiki jika ada kekurangan.

\section{Metode}

Pada penelitian ini peneliti akan menggunakan pendekatan kualitatif. Metodologi kualitatif menurut Bogdan dan Taylor (1975) adalah suatu prosedur penelitian yang menghasilkan data deskriptif berupa kata-kata tertulis atau lisan dari orang-orang dan perilaku yang diamati (Prastowo, 2016). Pendekatan secara kualitatif dipilih karena peneliti ingin menggambarkan setting sosial secara lengkap mengenai proses rehabilitasi low vision yang dilakukan oleh Low Vision Yayasan Layak. Penelitian ini juga berusaha untuk menggambarkan sistem dari berbagai komponen dan faktor yang berkaitan dalam pemberian pelayanan kepada anak dengan gangguan penglihatan guna mencegah kebutaan.

Jenis penelitian yang akan peneliti gunakan dalam penelitian ini adalah penelitian deskriptif. Menurut Sarantakos, penelitian deskriptif biasanya dilakukan untuk menggambarkan sistem sosial, hubungan sosial atau kejadian sosial, memberikan informasi sebagai latar belakang tentang suatu pokok 
masalah maupun untuk membangkitkan penjelasan atau eksplanasi (Suharjito, 2014). Data yang akan diperoleh nantinya berasal dari observasi langsung, wawancara, foto, dan juga dokumen milik pribadi.

\section{Hasil dan Diskusi}

\section{Evaluasi Proses Program Rehabilitasi Low Vision:}

Standar Praktik Terbaik (Best Standard Practice)

Standar Sarana dan Prasarana

Jika melihat Peraturan Pemerintah Republik Indonesia nomor 39 tahun 2012 tentang penyelenggaraan kesejahteraan sosial pasal 41, beberapa hal penting yang menjadi standar dalam pelaksanaan rehabilitasi sosial atau dalam hal ini rehabilitasi low vision telah terpenuhi. Berikut pembahasannya:

Pertama adalah ruang perkantoran yang dimaksud pada pasal 41 tersebut beberapa diantaranya telah terpenuhi seperti halnya ruang kerja bagi para pimpinan ataupun petugas seperti petugas refraksionis optisien, petugas rehab, petugas administrasi, dan juga receptionist. Kedua, ada ruang teknis yang tersedia dia Low Vision Yayasan Layak berupa ruang clinical assessment dan juga functional assessment. Dua ruangan teknis ini sudah ideal untuk pelaksanaan pemeriksaan klien, karena memang dua ruangan ini memiliki ukuran yang cukup luas, yaitu 3,6 m x 3,3 m untuk ruangan refraksionis optisien dan 4,2 m x $3 \mathrm{~m}$ untuk ruangan rehabilitasi. Beberapa ruangan yang tertera pada pasal 41 tersebut memang tidak semuanya terpenuhi karena pengurus dan para petugas juga meyakini bahwa Low Vision Yayasan Layak memiliki keterbatasan ruangan sehingga mereka memaksimalkan ruangan yang ada untuk melakukan rehabilitasi.

Ketiga adalah ruang untuk umum di mana tersedia ruang tunggu yang menjadi ruangan yang paling luas yang berukuran $6 \mathrm{~m}$ x 3,3 m, gudang yang cukup untuk menyimpan semua file dan peralatan, kamar mandi yang didesain ramah bagi anak low vision dan dijaga untuk selalu tetap bersih dan juga tempat parkir bagi keluarga klien yang datang dengan membawa kendaraan. Keempat adalah tenaga pelayanan sosial yang terdiri dari petuguas keuangan, receptionist, refraksionis optisien, dan juga petugas rehab. Untuk petugas lapangan sejauh ini telah memenuhi kualifikasi yang ditetapkan oleh lembaga. Kelima adalah peralatan yang pada bab sebelumnya telah dijelaskan berbagi macam alat baik untuk memeriksa klien seperti trial set, streak retinoscope, dan juga snellen chart. 
Selain alat untuk memeriksa klien, Low Vision Yayasan Layak juga menyediakan alat bantu optik seperti kacamata, hand magnifier, serta telescope dan juga alat bantu non optik seperti penyangga buku, typoscope dan juga lampu belajar. Semua alat yang digunakan tersebut sudah sangat lengkap untuk melakukan pemeriksaan terhadap klien. Akan tetapi harus ada peningkatan kualitas dari alat tersebut setiap tahunnya.

Keenam yaitu alat transportasi berupa mobil yang biasanya digunakan untuk membawa petugas berpindah-pindah tempat untuk memberikan pelayanan dan juga sosialisasi. Tidak jarang juga alat transportasi tersebut digunakan untuk menjemput dan mengantar klien. Mobil milik Low Vision Yayasan Layak sejauh ini sangat membantu para klien yang datang jika klien tersebut tidak mempunyai kendaraan. Terakhir, ketujuh adalah pangan yang biasanya diberikan oleh para petugas yang dapat berupa snack atau makan siang. Pangan yang diberikan kepada para klien secara tidak langsung membuat para klien dan keluarganya merasa nyaman dan percaya bahwa Low Vision Yayasan Layak benar-benar peduli dengan para kliennya.

Walaupun dari Peraturan Pemerintah Republik Indonesia nomor 39 tahun 2012 tentang penyelenggaraan kesejahteraan sosial pasal 41 tidak semuanya terpenuhi, akan tetapi sarana dan prasarana serta fasilitasi yang tersedia di Low Vision Yayasan Layak sudah mewakili dan dapat menunjang program rehabilitasi low vision. Seperti yang dijelaskan oleh salah satu pengurus dari Low Vision Yayasan Layak berikut ini:

Sejauh ini sarana dan prasarana, ruangan dan alat-alat yang digunakan saya rasa sudah cukup memadai gitu. Karena yang kita bantu anak dengan gangguan penglihatan, low vision. Untuk sarana yang ada ini sudah sangat memadai untuk bisa menjadi lembaga untuk rehab low vision. Untuk alat yang tersedia ini sudah sesuai standar sih. Hmm kalau menurut saya, semua sarana pendukungnya itu sudah diatas standar minimum.

\section{Standar Proses}

Seluruh tahapan rehabilitasi yang dijalankan oleh para petugas telah sesuai dengan tahapan yang telah ditetapkan oleh pemerintah dalam Peraturan Menteri Sosial Nomor 7 Tahun 2017 tentang standar Habilitasi dan Rehabilitasi Sosial Penyandang Disabilitas. Para klien yang datang diarahkan kebagian pendaftaran dan bersamaan dengan itu para petugas melakukan pendekatan awal, mencoba menjalin relasi dan melontarkan beberapa pertanyaan yang 
berkaitan dengan latar belakang klien. Pada tahap pertama inilah proses konsultasi awal dilakukan dan bersamaan dengan itu para petugas akan mengidentifikasi masalah klien.

Tahap kedua adalah pengungkapan dan pemahaman masalah. Dalam tahap ini biasanya para petugas mengumpulkan data dan informasi dari keluarga terdekat. Jika klien memiliki riwayat medis seringkali para petugas juga bertanya terkait riwayat penyakit dari klien dan membahas itu dengan keluarganya. Tahap ketiga adalah penyusunan rencana pemecahan masalah. Dalam tahap ini petugas beserta klien dan keluarganya bersama-sama membuat skala prioritas kebutuhan klien. Petugas juga akan merujuk klien ke beberapa rumah sakit jika klien memang butuh tindakan medis. Dalam tahap ini juga dilakukan kesepakatan jadwal pelaksanaan dari pemecahan masalah.

Tahap keempat adalah pemecahan masalah. Pada tahap ini klien diperiksa lebih lanjut terkait gangguan penglihatannya. Pemeriksaan yang dilakukan adalah tes klinikal dan fungsional. Setelah itu klien akan menerima bimbingan dan dilatih menggunakan alat bantu setelah alat bantu yang diperlukan sudah tersedia klien akan langsung diberikan kepada klien. Tahap kelima adalah resosialiasi. Pada tahap ini petugas melibatkan keluarga dengan tujuan keluarga mengetahui apa saja yang dibutuhkan klien dan bagaimana memperlakukan klien dengan baik dan benar. Contohnya para petugas memberikan informasi bahwa klien tidak mampu melihat tulisan kecil, maka keluarga khususnya orang tua harus memperlihatkan tulisan-tulisan dengan ukuran yang diperbesar

Tahapkeenamadalahterminasi.Padatahapiniparapetugasmengidentifikasi keberhasilan yang telah dicapai dari rehabilitasi yang dilakukan. Terminasi atau pemutusan hubungan biasanya dilakukan apabila tujuan rehabilitasi telah tercapai, klien dirujuk ke lembaga lain, klien mengundurkan diri, atau klien meninggal dunia. Tahap ketujuh adalah bimbingan lanjut, yaitu merupakan kegiatan pemantauan atau evaluasi pascapelayanan kepada klien.

Secara keseluruhan tahapan rehabilitasi yang dijalankan oleh Low Vision Yayasan Layak telah sejalan dengan peraturan dari menteri sosial, walaupun ada sedikit perbedaan yaitu Low Vision Yayasan Layak menempatkan terminasi di bagian paling akhir dari tahapan pelayanan. Jadi jika yayasan telah melakukan terminasi dengan klien itu berarti sudah tidak akan kegiatan konsultasi yang dilakukan klien dengan para petugas. 
Evaluasi Proses Program Rehabilitasi Low Vision Yayasan Layak Jakarta dalam Upaya Pencegahan Kebutaan pada Anak

- Habib Rachman Aji dan Ahmad Zaky

\section{Kebijakan}

Kebijakan dalam penelitian ini membahas siapa saja yang layak mendapat pelayanan dan bantuan serta membahas kriteria seperti apa yang harus dimiliki oleh para sumber daya manusia yang bertugas di Low Vision Yayasan Layak. Low Vision Yayasan Layak menjadikan anak berusia 0-18 tahun sebagai target utama dari program rehabilitasi low vision. Dalam hasil temuan telah diketahui bahwa memang banyak anak-anak dengan gangguan penglihatan yang telah dilayani dan menjalankan semua tahapan rehabilitasi low vision. Alat bantu bersubsidi bagi klien yang kurang mampu pun juga telah diberikan kepada anak-anak yang memang membutuhkan.

Untuk sumber daya manusia yang bekerja di Low Vision Yayasan Layak saat ini dirasa telah relevan dengan kriteria yang ditetapkan oleh pihak Yayasan Layak dan juga sesuai dengan Peraturan Menteri Sosial Republik Indonesia nomor 16 tahun 2017 tentang standar nasional sumber daya manusia penyelenggara kesejahteraan sosial. Pada pasal 4 ayat 1 dijelaskan bahwa sumber daya manusia penyelenggara kesejahteraan sosial terdiri atas Tenaga Kesejahteraan Sosial, Pekerja Sosial, Relawan Sosial, Penyuluh Sosial.

Jika melihat pembahasan pada bab sebelumnya perihal kebijakan Low Vision Yayasan Layak tentang kualifikasi para petugas dirasa sudah cukup relevan. Di mana untuk petugas lapangan yang saat ini dimiliki oleh Low Vision Yayasan Layak diisi oleh dua orang petugas yang bukan merupakan pekerja professional tetapi telah dilatih dan dididik secara professional untuk menjalankan tugas pelayanan dan penanganan masalah sosial dan juga satu orang pekerja professional yang yang memiliki kompetensi dan profesi pekerjaan sosial, dan juga memiliki kepedulian dalam pekerjaan sosial yang dapat diperoleh dari pendidikan, pelatihan serta pengalaman praktik pekerjaan sosial untuk melaksanakan tugastugas pelayanan dan penanganan masalah sosial.

\section{Tujuan Proses (Process Goal)}

Secara umum tujuan merupakan target yang bersifat luas yang ingin dicapai oleh suatu organisasi atau lembaga. Tujuan utama dari program rehabilitasi low vision Yayasan Layak adalah pencegahan kebutaan khususnya pada anak. Untuk mendukung target tersebut Yayasan Layak berupaya untuk mengembangan model layanan rehabilitasi yang komprehensif dan terintergrasi dengan pelayanan kesehatan, pendidikan, dan masyarakat. Low Vision Yayasan Layak 
juga berupaya menanamkan sikap peduli terhadap keluarga klien khususnya orang tua karena dengan kepedulian tersebut nantinya akan membantu klien dalam proses rehabilitasi.

Low Vision Yayasan Layak bekerjasama dengan tenaga pendidik atau guru baik di Sekolah Luar Biasa (SLB) maupun di sekolah inklusi. Kerjasama yang terjalin tersebut merupakan hasil dari proses yang dijalani para petugas selama ini. Dalam kerjasama tersebut pihak Low Vision Layak dan juga pihak sekolah mencari anak-anak yang memang mengalami gangguan pada penglihatan yang kemudian ditangani oleh para petugas sehingga anak-anak tersebut dapat terbantu dalam melakukan aktivitas sehari-hari dan juga dapat mencegah terjadinya gangguan penglihatan yang semakin parah. Sampai saat ini petugas berupaya untuk menyadarkan para orang tua atau keluarga terdekat untuk lebih peduli dan bertindak cepat jika klien membutuhkan penanganan medis.

\section{Kepuasan Klien}

Kepuasan klien dapat diartikan sebagai suatu keadaan di mana hasil dari suatu jasa sesuai dengan harapan klien. Jika jasa yang diberikan dapat memenuhi harapan para klien tentunya mereka akan merasa puas, dan sebaliknya jika jasa yang diberikan tidak memenuhi ekspektasi para klien mereka akan merasa tidak puas dengan suatu pelayanan. Sejauh ini pernyataan para informan seperti klien, orang tua dan guru bersifat positif dan sebagian besar dari mereka mengatakan bahwa mereka puas dengan apa yang diberikan oleh para petugas.

Zeithml, Bitner dan Gremler (2009) dalam Jurnal Adminstrasi Bisnis dari (Apriyani dan Sunarti,2017) memaparkan lima dimensidalam kualitaspelayanan diantaranya adalah keandalan (reliability), daya tanggap (responsiveness), keyakinan (assurance), kepedulian (empathy) dan bukti langsung (tangible). Keandalan (reliability) adalah kemampuan para petugas dalam memberikan jasa atau pelayanan sesuai dengan janji yang telah disepakati pada awal pertemuan dengan handal dan akurat.

Berdasarkan hasil temuan penelitian peneliti telah mengetahui pendapat para klien, guru dan orang-orang terdekat klien bahwa sejauh ini program dari rehabilitasi low vision berjalan dengan baik, sesuai rencana dan tepat sasaran. Klien yang memang membutuhkan rehabilitasi telah diobservasi dan ditangani sesuai hasil observasi dan juga hasil diagnosa dari tenaga medis yang sebelumnya menangani klien tersebut. Para klien juga telah mendapatkan alat 
Evaluasi Proses Program Rehabilitasi Low Vision Yayasan Layak Jakarta dalam Upaya Pencegahan Kebutaan pada Anak

- Habib Rachman Aji dan Ahmad Zaky

bantu sesuai dengan kebutuhan mereka. Hal tersebut sesuai dengan penjelasan salah satu informan yang merupakan seorang guru di sekolah inklusi sebagai berikut:

Yang diberikan oleh Yayasan Layak itu menurut saya sangat tepat sasaran diantaranya karena diawali oleh assessment dari beberapa anak ya kan, kemudian dari assessment itu kemudian diberikan kepada anak-anak yang memang dari hasil assessment itu anak-anak itu perlu mendapatkan layanan dari Yayasan Layak.

Ketanggapan (responsiveness) adalah kemampuan yang harus dimiliki oleh para petugas untuk membantu para klien dengan cepat, tepat dalam menghadapi permintaan, pertanyaan, keluhan dan juga permasalahan yang dialami oleh klien. Sejauh ini orang-orang terdekat klien mengatakan bahwa para petugas telah bersikap cepat dan tanggap dalam menangani klien yang butuh pertolongan seperti saat klien membutukan pertolongan medis dan juga apabila klien belum mendapat alat bantu atau alat bantu yang digunakan rusak, hilang atau kurang nyaman makan para petugas bertindak cepat dalam merespon. Seperti yang pernyataan dari salah satu informan yang merupakan pengasuh di Panti Sosial Bina Netra Bekasi yang ditanya perihal respon para petugas ketika klien membutuhkan pertolongan berikut ini:

Ya sangat cepat dan tanggap, diantaranya contohnya saja ketika saya diberi tahukan bahwa ada pembagian kacamata banyak, ada anak yang tidak terdaftar tetapi kemudian diperiksa atau di assessment itu anak itu seharusnya menggunakan kacamata dan harus diberikan layanan, maka Yayasan Layak ini cepatsekali melayani, jadi tidak hanya apa yang ditemukan saat assessment pada satu itu tetapi saat ada tambahan-tambahan maka mereka cepat sekali untuk memberikan alat-alat atau bantuan.

Keyakinan (assurance) adalah kemampuan yang harus dimiliki oleh pemberi layanan atau petugas untuk memunculkan rasa percaya dan yakin bahwa para petugas mampu untuk membantu klien. Keyakinan ini mencakup pengetahuan, kemampuan, kesopanan, dan sifat lain yang dapat dipercaya oleh para klien. Jika menilai dari pengetahuan dan kemampuan para petugas sejauh ini para petugas telah menerapkan ilmu yang sebelumnya sudah mereka dapat. Baik itu ilmu yang didapat saat mereka menjalankan studi atau ilmu yang didapat dari pelatihan-pelatihan yang terus mereka ikuti sampai sekarang. Dari pelatihan tersebut tentunya para petugas mendapatkan ilmu baru yang bisa diterapkan dalam program rehabilitasi low vision. 
Selain pengetahuan dan kemampuan hal lain yang berpengaruh dalam timbulnya kepercayaan klien dan keluarganya adalah kesopanan. Berdasarkan penilaian keluarga klien sejauh ini para petugas telah bersikap ramah dan sopan baik itu sopan kepada klien ataupun keluarganya. Secara tidak langsung sikap sopan yang ditunjukkan oleh para petugas akan memunculkan kesan nyaman dan tentunya kepercayaan dari klien beserta keluarganya terhadap para petugas.

Kepedulian (empathy) adalah kemampuan para petugas untuk membangun rasa peduli dan perhatian kepada klien. Para petugas juga harus memahami keinginan dan juga kebutuhan dari para klien. Sejauh ini para petugas berusaha untuk menjaga hubungan sebaik mungkin dengan para klien dan keluarganya dengan rutin melakukan follow up dan evaluasi. Kepedulian yang diberikan para petugas kepada klien juga dilakukan untuk memancing supaya keluarga atau bahkan orang-orang terdekat klien juga peduli, memberikan perhatian penuh kepada klien sehingga nantinya proses rehabilitasi akan berhasil dilakukan.

Bukti langsung (tangible) dalam hal ini adalah kemampuan dari Low Vision Yayasan Layak dalam menunjukkan eksistensinya pada masyarakat. Fasilitas fisik, peralatan, dan penampilan perorangan merupakan bukti yang diberikan oleh pemberi layanan. Untuk fasilitas di Low Vision Yayasan Layak saat ini dinilai cukup bagus oleh beberapa informan. Selain menata setiap ruangan untuk selalu bersih dan rapih, para petugas juga telah mendesain ruangan tersebut terlihat ramah anak terutama bagi mereka yang mengalami kesulitan dalam melihat. Selain itu, dari segi penampilan perorangan dan juga peralatan yang digunakan oleh para petugas dianggap telah memenuhi standar dan membuat para klien beserta keluarga percaya dengan apa yang diberikan oleh Low Vision Yayasan Layak sejauh ini.

\section{Kesimpulan}

Sejauh ini setiap ruangan yang tersedia di sana dirasa telah cukup untuk melaksanakan proses rehabilitasi. Hanya saja para petugas merasa untuk ruang manajemen yang juga dipakai sebagai ruang rapat dirasa agak sempit yang membuat mobilitas para petugas sedikit terganggu. Tetapi walaupun begitu mereka tetap memanfaatkan ruangan tersebut semaksimal mungkin. Sementara untuk peralatan baik alat untuk memeriksa klien maupun alat bantu baik itu 
optik maupun non optik dinilai telah cukup dan memenuhi standar. Untuk standar proses, Low Vision Yayasan Layak telah menjalankan proses rehabilitasi sesuai dengan Peraturan Menteri Sosial nomor 7 tahun 2017 tentang standar habilitasi dan rehabilitasi sosial penyandang disabilitas.

Low Vision Yayasan Layak memberikan subsidi dalam pemberian alatbantu. Dalam pemberian subsidi tersebut para petugas telah mencari data seputar klien terlebih dahulu, jika dirasa memenui kriteria maka klien tersebut akan menerima subsidi. Untuk klien dan keluarga yang merasa cukup mampu dapat langsung melunasinya langsung atau mencicilnya. Sementara bagi klien yang merasa kurang mampu dapat membayar setengah harga bahkan sama sekali tidak membayar dengan syarat klien harus memberikan surat keterangan tidak mampu dari RT ataupun RW di tempat klien tinggal. Sementara untuk sumber daya manusia yang telah tersedia telah memenuhi kriteria yang ditetapkan oleh lembaga, akan tetapi dibutuhkan petugas tambahan untuk membantu menjalani program rehabilitasi tersebut.

Tujuan Low Vision Yayasan Layak kini sudah ada yang tercapai, yaitu layanan yang diberikan telah terintegrasi dengan beberapa rumah sakit, sekolah dan kader masyarakat, akan tetapi mereka masih harus memperluas jaringan layanan, meningkatkan kualitas layanan dan menjalin kerjasama dengan rumah sakit, sekolah dan kader masyarakat yang lebih banyak supaya akan lebih banyak anak dengan gangguan penglihatan yang tertangani.

Para petugas berupaya untuk bersikap positif kepada para klien dan keluarganya. Sejauh ini layanan yang diberikan telah menyasar kepada orang khususnya anak-anak yang mengalami gangguan penglihatan. Beberapa informan mengatakan bahwa para petugas telah bersikap cepat dan tanggap jika ada masalah yang dialami oleh klien. Untuk bersikap cepat dan tanggap dalam melayani klien para petugas berkoordinasi dan membuat skala prioritas mengenai permasalahan yang dialami oleh beberapa klien. Salah satu informan yang merupakan seorang guru di sekolah inklusi mengatakan guru di sekolah tersebut telah percaya dengan kemampuan para petugas karena apa yang diberikan sejauh ini telah bermanfaat bagi anak-anak di sekolah tersebut.

Para petugas berusaha untuk menjalin hubungan sebaik mungkin dan membangun kepedulian dengan klien beserta keluarganya dengan cara rutin bertukar kabar dan bertanya terkait kondisi para klien. Bukti bahwa Low Vision Yayasan Layak berusaha menjaga kepuasan klien adalah dengan cara menjaga 
penampilan, bersikap seramah mungkin dan juga menyediakan fasilitas yang ramah bagi anak-anak dengan gangguan penglihatan.

\section{Daftar Pustaka}

Apriyani, Aliyyah, D dan Sunarti. (2017). Pengaruh Kualitas Pelayanan Terhadap Kepuasan Konsumen (Survei pada Konsumen The Little A Coffee Shop Sidoarjo). Jurnal Administrasi Bisnis, Vol. 2.

Asrorudin, M. (2014). Dampak Gangguan Penglihatan dan Penyakit Mata terhadap Kualitas Hidup (Vision-Related Quality of Live) pada Populasi Gangguan Penglihatan Berat dan Buta Indonesia; Subpenelitian Studi Validasi Data Kebutaan Hasil RISKESDAS 2013 dan Identifikasi Etiologinya. Jakarta: Universitas indonesia.

Dalope, Junifer M.L. (2017). Prevalansi Penurunan Visus pada Siswa Berkebutuhan Khusus di SLB Kasih Angelia Kota Bitung Tahun Ajaran 2017/2018. Jurnal e-Clinic (eCI), Vol. 2.

Depkes. (2018). Indonesia Perlu Waspadai Gangguan Penglihatan. Diakses dari http://www.depkes.go.id/article/view/18110100003/indonesia-perlu-waspadai-gangguan-penglihatan.html

Detikcom. (2015). Cerita Nurul Besarkan Anak Bungsunya Yang Low Vision.

Diakses dari https://health.detik.com/berita-detikhealth/d-3048504/ cerita-nurul-besarkan-anak-bungsunya-yang-low-vision.

Layak, Yayasan. (2018). Profil Yayasan Layak. Diakses dari https://yayasanlayak.wordpress.com/profile-yayasan-layak/.

Prastowo, A. (2016). Metode Penelitian Kualitatif Dalam Perspektif Rancangan Penelitian. Yogyakarta: Ar-Ruzz Media.

Suharjito, D. (2014). Pengantar Metodologi Penelitian. Bogor: IPB Press. 